\title{
Lime mortars with heat treated clays and ceramic waste: A review
}

Construction and Building Materials 73 (2014), 125-136 (DOI: 10.1016/j.conbuildmat.2014.09.028)

Gina Matias ${ }^{a_{*}}$, Paulina Fariab ${ }^{b}$ Isabel Torres ${ }^{c}$

a ITeCons - Institute for Research and Technological Development in Construction Sciences, Rua Pedro Hispano, s/n, 3030-289 Coimbra, Portugal

${ }^{\mathrm{b}}$ UNIC, Department of Civil Engineering, Faculty of Sciences and Technology of NOVA University of Lisbon, Quinta da Torre, 2829-516 Caparica, Portugal

${ }^{c}$ Department of Civil Engineering, Faculty of Sciences and Technology of the University of Coimbra, Rua Luís Reis Santos - Pólo II, 3030-788 Coimbra, Portugal

\section{Abstract}

The formulation and use of lime mortars with ceramic particles has, in the past, been a very common technique. Knowledge of such used techniques and materials is fundamental for the successful rehabilitation and conservation of the built heritage. The durability that these mortars have shown encourages the study of the involved mechanisms, so that they may be adapted to the current reality. The considerable amount of waste from old ceramics factories which is sent for disposal might present an opportunity for the production of reliable improved lime mortars. In this paper a number of studies that characterize old building mortars containing ceramic fragments are reviewed. The most important research undertaken on laboratory prepared mortars with several heat treated clays types is presented, specifically with incorporated ceramic waste. Some studies on the pozzolanicity of heat treated clays are examined and the heating temperatures that seem most likely to achieve pozzolanicity are presented. It was verified that some heating temperatures currently used by ceramic industries might correspond to the temperatures that will achieve pozzolanicity.

\section{Highlights:}

- The use of air lime mortars with ceramics is well known from the past.

- Fine particles of heat treated clays have proven to be potentially pozzolanic.

- Repair mortars must have a behaviour similar to the ones already in place.

- Knowledge of old mortars is fundamental for the conservation of the built heritage.

- The use of ceramic waste in mortars has technical and environmental advantages.

Keywords: heat treated clay; ceramic waste; air lime; repair mortar; pozzolanicity. 


\section{Introduction}

Ceramic dust and grains, mostly from bricks, tiles or decorative elements, have been widely used in mortars in the past. The variety of these materials was mainly influenced by their availability and it was observed that when they were combined with certain substances the resulting mortars have improved characteristics. Over time, it has been demonstrated that the addition of small ceramic particles confers improved characteristics on lime mortars and that pozzolanic reactions might occur, thus providing mortars with hydraulic properties. The economic advantage and the quick-setting property of Portland cement led to a growth in its production for several decades, which in turn resulted in a decline in the use of air lime mortars. However, cementbased products were found to be incompatible when it came to repairing and replacing mortar in old buildings. The effectiveness of repair mortar is based on properties such as flexural and compressive strength, water vapour permeability, water absorption by capillary action and drying. When well selected and applied, repair mortar can help prevent severe pathologies that might cause serious damage to a building. The repair of lime-based masonry systems with cement-based mortars is a great example of a solution that is not only not compatible with the old systems, because of their short life span, but, that can also cause strong and accelerated degradation of the pre-existing materials.

When combined with lime, ceramic dust may act as pozzolan when its silica and alumina content react with the calcium oxide from lime. In addition to the specific surface area of the ceramic material being significant, this reaction is essentially governed by the heating temperatures and consequent amounts of silica and alumina in the amorphous state.

Although heating temperatures used in more recent industrial ceramic products may be higher and more homogeneous than older ones, the behaviour of their waste when used as lime mortar constituents is not yet well known. However, their use may be an effective possibility.

About $30 \%$ of the industrial ceramic products are considered unfit for use and are in most cases sent to landfill. Their great strength and resistance to degradation make the problem of processing ceramics waste unmanageable [1]. Therefore, incorporating these waste materials in lime mortars might prove to be both technically and environmentally advantageous.

Previous research has shown that while there have been some studies performed on mortars with ceramics waste, most of them relate to cement mortars. On the other hand, results from air lime mortars studies have not offered an in-depth characterization of industrial ceramics waste, which should be systematize. 
This paper sets out to review the environmental aspects and the most significant research related to heat treated clays and ceramics incorporated in old mortars, in order to assess the viability of using waste from ceramics plants as a component in repair and substitution lime-mortars.

\section{Historical background}

Research work carried out in old buildings and archaeological sites indicates that the use of hydrated lime mortars with several additions was very common. These additions were intended to improve the behaviour of mortar and were obtained from natural sources in their earliest forms. Products such as heat treated clay and ash have been often detected in old mortars. It is also known that heat treated clays from ceramic products such as bricks were extensively milled and incorporated in lime mortars in ancient times.

The first records of hydrated lime mortars with clayish additions date back to constructions in Babylon from 3000 B.C. [2]. It is believed that the Phoenicians, whose period of influence lasted from 1200 to 800 B.C., also fostered the use of these mortars [3]. Signs of the use of brick waste in the rendering mortar of water cisterns were also detected in the period of Solomon's kingdom (970 to 931 B.C.) [3]. Later, mortars from II

B.C. with ceramic pozzolanic materials were also found in Greece [2].

However, it is in the Roman Empire that the use of such materials becomes more evident. The first documents that specify the use of brick shards in mortars are by Catone and Vitruvius [3]. In that period, brick dust was frequently used as a pozzolan in the absence of natural ones [4]. It was given various names. Most common were opus testaceum and cocciopesto [2,5]. These materials were intended to give hydraulic characteristics to air lime mortar and sometimes waterproofing features. Cocciopesto mortar contained milled brick, which could be in the form of both dust and grain. Mortars with brick dust were applied as wall rendering or plastering materials and for floor covering. Crushed bricks were more often used for masonry mortars, especially in structural elements, such as arches or foundations [2], as well as for rendering elements with hydraulic requirements, such as baths, water conduits, reservoirs and cisterns. Nowadays it is common to find these mortars in Roman archaeological sites [6-13], but it is also possible to find them in later constructions, for example from the $14^{\text {th }}, 15^{\text {th }}$ and $16^{\text {th }}$ centuries [8, 14-17], up to the $19^{\text {th }}$ century [18]. In fact, a considerable number of historical monuments from the Ottoman period, and particularly from the Byzantine period, were built with this type of mortars. Constructions such as Hagia Sophia Cathedral $[6,19]$, the Medieval City of Rhodes [19], and churches, monasteries and cathedrals in Kiev [20] and Israel [21], dating back to the Byzantine period, are just a few examples of the wide use of ceramic fragments in lime mortars at that time. In these cases, several researchers highlight, not only the waterproofing characteristic 
of the mortars, which is very important in dry climatic conditions [21,22], but also their performance as important elements of earthquake resistant masonry systems [20,23,24].

This technique spread throughout Europe and other continents. In India there are records of brick waste incorporation in mortars, called surkhi [25] and in Arabian countries and Turkey this product was known as homra and horasan, respectively [8]. In Oman this type of mortar was known as sarooj [26]. Until the first hydraulic binders came on to the scene, mortar made with heat treated clay obtained from milled by-products was quite long-lasting and reliable. Its considerable number of advantages led to it being used for many centuries. The ease of finding this type of mortar in historic buildings till this day is a good indicator of its longevity.

\section{The reaction mechanisms}

Limestone $\left(\mathrm{CaCO}_{3}\right)$ treated at high temperatures (approximately $\left.900^{\circ} \mathrm{C}\right)$ gives way to calcium oxide $(\mathrm{CaO})$, usually known as quicklime, in a decomposition process which also releases carbon dioxide $\left(\mathrm{CO}_{2}\right)$. When it reacts with water, calcium oxide stabilizes and becomes hydrated lime, or calcium hydroxide $\left(\mathrm{Ca}(\mathrm{OH})_{2}\right)$. $\mathrm{Ca}(\mathrm{OH})_{2}$, traditionally called slaked or hydrated lime, was used for centuries in all types of mortar as a powder or as a putty (distinguished by the amount of water added for the reaction). It differs from currently used hydraulic binders because it hardens slowly, due to a reaction occurring between the lime and the $\mathrm{CO}_{2}$ in the atmosphere, which is consumed. This reaction generates calcium carbonate $\left(\mathrm{CaCO}_{3}\right)$, the parent compound of lime, and water, which is released at the same time. This carbonation process described is slow and affected by several factors such as the amount of moisture present (above $8 \%$ there is no visible formation of $\mathrm{CaCO}_{3}$ ), the temperature, the $\mathrm{CO}_{2}$ concentration and the porous structure of the material [27]. There is usually an increase in weight due to the transformation of portlandite $\left(\mathrm{Ca}\left(\mathrm{OH}_{2}\right)\right)$ into calcite or aragonite $\left(\mathrm{CaCO}_{3}\right)$ [27].

The $\mathrm{Ca}(\mathrm{OH})_{2}$ powder can also be turned into a distinct putty that is dispersed in water. Different preparation methods and different ways of using air lime will result in different characteristics [28].

The silica $\left(\mathrm{SiO}_{2}\right)$ and alumina $\left(\mathrm{Al}_{2} \mathrm{O}_{3}\right)$ present in pozzolanic materials, when combined with the $\mathrm{Ca}(\mathrm{OH})_{2}$ and water (required for hydration) form calcium silicates and calcium aluminates. The final product is therefore able to harden in the presence of water, whereas air lime mortar hardens by exposure to air [29]. The interaction of air lime with heat treated bricks, produced at specific temperatures, has been studied in order to learn about the mechanisms that allow hydraulicity changes in air lime mortars $[2,5,8,9,11$ $13,17,18,30-37]$. The reactivity of these materials, which is generally considered pozzolanic, may be 
influenced by several features: the amount of amorphous silica and alumina, the temperature and the duration of the heat treatment, the amount and type of original clays, the particle size distribution and specific surface [38], and the chemical reactions involved. Most studies indicate that the pozzolanic reaction depends mainly on the $\mathrm{SiO}_{2}$ and the $\mathrm{Al}_{2} \mathrm{O}_{3}$ available to react with the $\mathrm{Ca}(\mathrm{OH})_{2}$, responsible for fixing the calcium hydrate $(\mathrm{CaH})[8]$ in air lime mortars and in natural hydraulic lime mortars. Böke et al. [8] reported that in the $14^{\text {th }}$ and $15^{\text {th }}$ centuries, brick waste pozzolanicity in mortars was essentially influenced by the amount of clay minerals.

Materials have to be processed and fired in order to determine their pozzolanicity/reactivity rate. Heating leads to the loss of water from the mineral structure and the disruption of the crystal structure of silica and alumina [39]. A significant amount of material in the amorphous state is thus produced during controlled heating periods at specific heating temperatures, believed to range from $600^{\circ} \mathrm{C}$ to $900^{\circ} \mathrm{C}$ for most of clays. However, according to Böke et al. [8], heating temperatures above $800^{\circ} \mathrm{C}$ induce reactivity loss due to the formation of mineral phases, such as mullite and cristobalite, and also through specific surface reduction. Other authors mention potential pozzolanicity above $900^{\circ} \mathrm{C}$ thanks to quick fusion and cooling of the minerals, which may lead to new amorphous phases [25]. Though these studies show some dissent, for some materials exposure to high temperatures intensifies pozzolanic reactivity, which increases their porosity. This can lead to water behaviour that does not favour the production of mortar [40]. Heating temperatures may be estimated considering that when rich clay materials are submitted to high temperatures this generates the gehlenite $\left(800^{\circ} \mathrm{C}\right)$, anorthite $\left(850^{\circ} \mathrm{C}\right)$ and diopside $\left(900-1050^{\circ} \mathrm{C}\right)$ phases, while poor-clay materials generate products such as hematite, which starts to form at around $850^{\circ} \mathrm{C}$ [41]. Calcium Silicate Hydrates (C-S-H) may be generated by pozzolanic reactions or may be naturally occurring composites. Nowadays, about 30 different phases of crystalline $\mathrm{CSH}$ are known, usually with a low crystallinity degree at regular temperature and pressure conditions [42]. They may be classified differently according to predominant phases, being the most common Type I (honeycomb formation) or Type II (fibrous formation) [43]. Silicates and aluminates resulting from pozzolanic reactions, according to the reacting products, were analysed by several researchers. In the specific case of thermally treated clays, usually Type I C-S-H (between $\mathrm{CS}_{2} \mathrm{H}_{\mathrm{n}}$ and $\mathrm{C}_{3} \mathrm{~S}_{2} \mathrm{H}_{\mathrm{n}}$ ), $\mathrm{C}_{3} \mathrm{~S}_{2} \mathrm{H}_{\mathrm{n}}$ and $\mathrm{C}-\mathrm{S}-\mathrm{H}_{2}$ are formed [43]. Fibrous type C-S-H were also found in old crushed brick mortars [44].

Besides $\mathrm{C}-\mathrm{S}-\mathrm{H}$, pozzolanic reactions also originate aluminates and calcium aluminosilicate hydrates that, in the specific case of calcium hydroxide reaction with thermally treated clays, correspond to gehlenite $\left(\mathrm{C}_{2} \mathrm{ASH}_{8}\right)$, katonite $\left(\mathrm{C}_{3} \mathrm{AH} \mathrm{H}_{6}\right)$ and other forms of calcium aluminate hydrates $\left(\mathrm{C}_{4} \mathrm{AH}_{\mathrm{x}}\right)[38,43]$. 


\section{Characterization of pre-existing air lime mortars with ceramics}

A number of authors have studied the behaviour of air lime mortars with the aim of understanding and harmonizing mortars to be used for rehabilitation and conservation. Given its particular curing mechanisms, the durability of these mortars deserves special attention.

Marques et al. [45], for example, developed a methodology to characterize them to simplify the selection of repair mortars. They established two distinct steps, both essential to characterize and choose rehabilitation mortars: the distinctive analysis that determines the main components of mortars and their proportions, and the comparative characterization, which consists of replicating existing mortars and their physical and mechanical characterization for further comparison.

Firstly however, in order to reproduce mortars similar to the old ones there is a need to understand the materials, proportions and application techniques used in the past.

An exhaustive characterization using thermal analysis and X-ray diffraction (XRD) was performed on old ceramic materials by Moropoulou et al. [18]. These researchers collected a wide range of mortars from old buildings from several different historical periods, including mortars designated as "crushed brick mortars". They observed reactions that might be caused by calcium silicate formations at the brick fragment-lime interface and concluded that the penetration of lime into the smaller pores of the ceramic fragments increased the apparent density, which in turn increased strength. In terms of hydraulicity, these mortars are between cementitious mortars and typical lime mortars and the researchers classified them as "pozzolanic mortars". In this study, "cocciopesto" mortars from Hagia Sophia Cathedral were examined in detail and signs of hydraulicity were detected, probably from pozzolanic reactions between lime and brick fragments [5].

Moropoulou et al. $[2,30,31]$ developed a correlation matrix to classify historical mortars in terms of their mechanical and physicochemical properties. Among those studied were "typical lime" and "crushed brick" mortars. In these specific cases, lime mortars were found to have tensile strength below $0.4 \mathrm{MPa}$ and above $0.5 \mathrm{MPa}$, respectively. They characterized lime mortars with additions, such as materials of volcanic origin, milled bricks and tiles that worked both as pozzolans and aggregates. They calculated the most commonly used proportions and found that one of the most valued materials used in mortar production was milled brick, since it had numerous advantages. Using thermal analysis, they studied natural and artificial pozzolans present in old mortars. The pozzolan most often detected was ceramic dust [38]. 
In a similar study, Maravelaki-Kalaitzaki et al. [32] collected and characterized old mortars taken from several monuments in Crete. Researchers found air lime, hydraulic lime, lime-crushed brick and lime-natural pozzolan mortars dating back from the Minoan to Byzantine periods. They found that crushed brick mortar exhibited ample evidence of products from boundary reactions. Thermal analysis showed that the ratio between $\mathrm{CO}_{2}$ and chemically bound water of these mortars was an indicator of high hydraulicity (higher than the hydraulic lime mortars studied), although they contained less binding material and coarser aggregates. The tensile strength values obtained were the second highest, just after lime-natural pozzolan mortars, and they were in direct proportion to hydraulicity levels.

Santos-Silva et al. [11] analysed three mortar types collected from the archaeological Roman site of Tróia (baths and industrial facilities) in Portugal and found that one type in particular contained brick fragments (some greater than $5 \mathrm{~mm}$ ) and brick powder. XRD analysis determined that the specific mineral content (presence of mullite and absence of hydrated calcium chloroaluminate) in the brick fragments were a sign that the bricks were fired at a high temperature and compounds that suggest pozzolanic reactions and consequent hydraulic behaviour were also found.

Also in Portugal, in the historical town of Mértola, Santos-Silva et al. [12] collected four types of mortar with different functions. In the specific case of mortar used as a watertight surface layer of a cistern, it contained high amounts of crushed ceramics in dust, or coarser forms, and the most interesting finding was that there were large amounts of pozzolanic reaction products not only in the binder-ceramic interface but also throughout the binder. In some cases, the ceramics were completely blended in the lime. In the same context, Böke et al. [8] studied the characteristics of aggregate derived from brick milling and used in historical mortars, to understand the hydraulic behaviour of lime mortar. Clear signs of pozzolanicity were found in brick dust, which contained significant amounts of clay minerals with low calcium content and were calcinated at low temperatures. Some researchers [33] also analysed the influence of the calcination temperature of clays on their use as pozzolans in air lime mortars. The composition of mortars from two old buildings was studied and pozzolanicity from clay aggregates was detected. Some pozzolanicity tests to ascertain ideal calcination temperatures were also performed.

Another example of this type of research is the work developed by Velosa et al.[13] in which the composition of mortars from the Roman site at Conímbriga in Portugal was studied with respect to binder/aggregate ratio, particle size distribution, micro-structure and mineralogy, in order to improve the knowledge of mortars used in this site during the Roman period. Several mortars with ceramic particles, known as opus signinum, frequently found in Roman tanks, aqueducts and other water bearing constructions were analysed. These 
mortars contained brick fragments that acted as aggregate and introduced air, allowing a more efficient carbonation, as well as smaller particles, of less than $75 \mu \mathrm{m}$, that were considered to be a binder addition. Ugurlu and Böke [17] collected mortars from old Ottoman baths buildings looking to understand the mechanisms that justified the use of brick-lime mortars and plasters in these constructions. The formation of calcium silicate hydrates in the interface between lime and brick aggregates was confirmed and clear indicators of pozzolanicity were found.

Borsoi et al. [9] gathered mortars from the Roman Villa of Pisões in Portugal, and found that all mortars, whatever their different functions, contained ceramic and brick residues, both in dust and granular form. Using thermal and XRD analysis signs of pozzolanic reactions in those mortars were detected. Also, petrographic observations determined the occurrence of rims around brick fragments, caused by pozzolanic reactions with the binder.

Stefanidou et al. [46] analysed bedding and plastering mortars from cisterns and baths located in Greece, collected in old monuments from the Roman, Byzantine and Ottoman periods. Brick dust was found in Roman and Byzantine mortars and brick fragments used as aggregate were detected in mortars from all of the periods studied. The physico-mechanical, chemical and microstructural properties of the mortars were established and the researchers verified that the inclusion of brick as dust or fragments in hydrated lime mortars provided them high levels of hydraulicity. Despite the fact that brick fragments from structural mortars presented sizes ranging from 8 to $20 \mathrm{~mm}$, reactions between the binder and the fragments were detected. The high amounts of $\mathrm{SiO}_{2}, \mathrm{Al}_{2} \mathrm{O}_{3}$ and $\mathrm{Fe}_{2} \mathrm{O}_{3}$ from plastering mortars confirmed their high hydraulicity. Cardoso et al. [34] studied the ruins of Ammaia, a Roman village in the São Mamede Natural Park in Portugal, and also found several types of opus signinum mortar. The collected and analysed samples showed that ceramic fragments not only had different colours and shapes but their grain size also varied greatly. With thermal analysis, the researchers found that mortars with ceramic fragments suffered higher mass loss in the range of $200-650^{\circ} \mathrm{C}$, a common indicator of mortar hydraulicity.

It may be said that the studies performed by of the researchers mentioned above confirm that Mediterranean countries used, for a long period in history, ceramic fragments to produce high quality mortars with hydraulic properties, reliable even for structural purposes.

\section{Studies of the pozzolanicity of heat treated clays and ceramics}

Research work has been carried out to understand and explain why mortars with calcinated clays were used in the past. A number of authors ascertained that these materials have potential as pozzolans. 
Regarding the specific properties of these materials and the tests that might lead to conclusions about their pozzolanicity, some authors gathered industrial and natural products and studied their reactivity and, more especially, the ideal heating conditions to enhance it.

Faria-Rodrigues [47] gathered clayish raw material from a powder collector in a ceramic bricks factory, before the firing process. The raw material was characterized by XRD and was found to be a mixture of kaolinite with some illite and other phyllosilicates with quartz and traces of feldspar. The material was thermally treated and kept at $800^{\circ} \mathrm{C}$ and $600^{\circ} \mathrm{C}$ for 3.5 hours and at $700^{\circ} \mathrm{C}$ for 30 minutes. Cooling was slow. All these materials tested positive with the EN 196-5 [48] standard test [29]. The material thermally treated at $800^{\circ} \mathrm{C}$ for 3.5 hours had the highest pozzolanicity; the material treated at the lowest temperature but for a longer period $\left(600^{\circ} \mathrm{C}-3.5\right.$ hours) had similar pozzolanicity to that of the material treated at medium temperature, but for a short period $\left(700^{\circ} \mathrm{C}-30\right.$ minutes $)$.

Chakchouk et al. [49] studied the specific case of Tunisian clays and their potential as pozzolans. The researchers collected six types of clay and characterized their geotechnical and physicochemical properties. They concluded that the presence of kaolin in raw materials is a favourable condition when combined with the correct heating temperature and period. They found the highest pozzolanicity signs for these clays at a temperature close to $700 \stackrel{\circ}{\mathrm{C}}$.

Velosa [43] studied the pozzolanic reactivity of "brick dust" from two different origins. In the first case, the researcher used industrial unfired paste, which was later subjected to heating temperatures of $750^{\circ} \mathrm{C}, 950^{\circ} \mathrm{C}$ and $1100^{\circ} \mathrm{C}$, having noted in preliminary studies that $750^{\circ} \mathrm{C}$ would be the most suitable temperature to obtain pozzolanic reactions. In the second case, clays from layers from the Roman Empire period were collected and subjected to calcination temperatures of $700^{\circ} \mathrm{C}, 800^{\circ} \mathrm{C}, 900^{\circ} \mathrm{C}$ and $1000^{\circ} \mathrm{C}$, at a heating rate of $2^{\circ} \mathrm{C} / \mathrm{min}$ and with constant heating at the maximum temperature for 120 minutes. It was observed that for this specific case the ideal heating temperature was $800^{\circ} \mathrm{C}$.

The heat treated "bricks" were milled into dust and its pozzolanicity was determined. Velosa concluded that the brick dust contained high levels of silicon and iron, however it did not contain significant amounts of material in the amorphous state. This material would be classifiable as pozzolan according to EN 196-5 [48]. In this specific case, the ceramic dust incorporated in lime mortars led to an increase of the mechanical strength.

Miriello et al. [50] studied the influence of the milling process of clay brick powder on the reactivity between clay and lime. They prepared two lime-clay brick powder mixtures, one milled for 1 minute and the other for 8 hours, and studied the constituents of each mixture, both as a dry product and as a paste (at 30 days). The 
researchers noted that the particles of the 8-hour milled mixture were rounder and, as a paste, this mixture had only neoformed calcite, an indicator of a stronger binding power and thus of a better quality product. Budak et al. [33] also studied the potential pozzolanicity of heat treated clays and reported that clays commercialized in Turkey required heating at temperatures between $500^{\circ} \mathrm{C}$ and $700^{\circ} \mathrm{C}$ to improve performance.

Other researchers not only characterized the pozzolanicity of the products when isolated, but also produced mortars incorporating such products. Some examples of studies of the pozzolanicity of clays when integrated in cementitious mortars are listed in the following paragraphs.

He et al. [51] collected six standard clays which were first characterized chemically before being heat treated at different temperatures in order to assess the ideal reactivity conditions. The water demand and the compressive strength of cement mortars with the heat treated clays were determined and several tests were performed to verify their pozzolanicity. Ideal heating temperatures from $650^{\circ} \mathrm{C}$ (kaolinitic clay) to $930^{\circ} \mathrm{C}$ (ilitic clay) were obtained.

O'Farrell et al. [25] subjected clays to high heating temperatures, from $800^{\circ} \mathrm{C}$, at a heating rate of $100^{\circ} \mathrm{C} / \mathrm{h}$ and then maintained at constant temperature for 2 hours. The materials were then cooled at room temperature or by immersion in water. After that, they were included in cement mortars, partially substituting cement. Industrial brick waste was also included in similar mortars for further comparison. The authors observed that, although the initial compression strength of the heat treated clay mortars was greater than that of the residues, at a later age this behaviour reversed. However, heat treated clay mortars showed better results of expansion due to exposure to chlorides. In previous work, they had detected pozzolanic activity in bricks fired at $1000^{\circ} \mathrm{C}$. In 2003 the same researchers had collected several types of brick and analysed their influence on the porous and mechanical characteristics of cement mortars. They found that partial substitution of cement with brick dust in mortars changed the pore sizes significantly, which directly affected compressive strength [52].

Toledo Filho et al. [53] analysed the viability of partially replacing cement with brick waste in mortars. Promising results were obtained for $20 \%$ binder substitution. Parameters like the compressive strength and the elasticity modulus of cement mortars were not affected. Application of the Rietveld method showed that about $60 \%$ of brick waste was in the amorphous phase.

Silva et al. [54] evaluated the viability of adding ceramic dust from demolition waste to cementitious mortar in order to improve its behaviour in terms of mechanical strength, water absorption due to capillary action, shrinkage, water vapour permeability and durability. In relation to flexural and compressive strength, the 
increase at 28 days of curing was directly proportional to the increase of the percentage of replacement ceramics. This might indicate some kind of pozzolanic reactivity. Water absorption by capillary action was inversely proportional to the substitution percentage rise. This is due to the reduction of the sizes of the pores that may be filled with ceramic dust leading to a consequent reduction of the water absorbed. Mortars with ceramic waste resulted in an improved behaviour regarding water retention, since higher water retention capacity is beneficial to mortar in its hydration period.

Lavat et al. [55] evaluated the pozzolanic behaviour of tile waste heat treated at temperatures from $890^{\circ} \mathrm{C}$ to $1000^{\circ} \mathrm{C}$. They achieved quite positive results for the amount of amorphous material (kaolinite and illite) determined through chemical analysis (SEM-EDX, XRD and FTIR), and thus for pozzolanic reactivity. Waste used in this study was collected from an industry whose production process consisted of heat treatment of a previously prepared paste (biscuit) at temperatures from $900^{\circ} \mathrm{C}$ to $1000^{\circ} \mathrm{C}$, for 24 to 30 hours, in a tunnel kiln. Pozzolanic reactivity was determined with chemical tests performed on mortars produced in the laboratory during the curing period, and with the Frattini test, using a cement and a ceramic paste. They were able to confirm pozzolanicity of the material from the consumption of the portlandite present in the cement blends. Mechanical strength was also evaluated. They showed that cement substitution of $20 \%$ to $30 \%$ with ceramic waste did not significantly affect the mechanical behaviour of the blends.

Pereira-de-Oliveira et al. [56] collected ceramic tiles produced at temperatures ranging from $1100^{\circ} \mathrm{C}$ to $1200^{\circ} \mathrm{C}$ and bricks at temperatures form $800^{\circ} \mathrm{C}$ to $1000^{\circ} \mathrm{C}$ and analysed the viability of incorporating these materials in cementitious mortars. Potential pozzolanic reactivity was examined by performing compression strength tests and was only detected for the tiles.

Regarding studies of pozzolanicity of heat treated clays that involve research on lime mortars, several examples are mentioned below.

The Smeaton Project, carried out by Teutonico et al. [57], was intended to evaluate the behaviour of lime and cement mortars with pozzolanic additions for repairs and maintenance in old buildings. The specific case of Hadrian's Wall, from the Roman Empire, was studied. A wide range of compositions was characterized regarding their behaviour in the presence of water. The studied mortars contained dust from bricks heat treated at moderate temperatures $\left(950^{\circ} \mathrm{C}\right)$, and from firebricks heat treated at higher temperatures.

Promising results were obtained for compressive strength, especially from lime mortars with dust from bricks heat treated at lower temperatures. In some cases, the values were higher than those obtained from cement mortars studies. This might be due to pozzolanic reactions, possibly influenced by the heating temperature or the type of clay used to make the bricks. 
Baronio and Binda [40] studied the inherent pozzolanicity of ceramic bricks and clays by characterizing their chemical and mineralogical composition and also their capacity to retain calcium hydroxide. They ascertained that when exposed to certain high temperatures most clays showed signs of pozzolanicity. On the other hand, bricks produced in Italy in the 1990s exhibited low pozzolanicity, possibly because the heating temperature was too high or because the raw material contained low amounts of reactive clays. The same researchers studied Byzantine buildings whose masonry settlement joints contained brick dust and granules [3]. They analysed the pozzolanicity of old materials and tried to reproduce mortar samples similar to old ones, in which some kind of reaction in the binder-aggregate interface was observed. Although they did not reach conclusive results regarding pozzolanicity, they obtained mortars with satisfactory bulk density and deformability results after a long curing period.

Al-Rawas et al. [26] studied a well-known old pozzolan from Oman, which was produced from heat treatment of several local clays. They verified the pozzolanic potential with chemical and mineralogical tests for different heat treatments, meaning different heating temperatures and time periods. Also, these materials were used in lime-based mortars to determine what heat treatment would be more favourable for pozzolanicity. They found quite satisfactory values for heating temperatures between $730^{\circ} \mathrm{C}$ and $850^{\circ} \mathrm{C}$ and observed that for lower temperatures longer heating periods were preferable.

Cortina and Dominguez [58] analysed the behaviour of laboratory-prepared mortars with air lime and different types of chamotte, a type of ceramic waste used in the ceramics industry, fired at $1300^{\circ} \mathrm{C}$ and $1000^{\circ} \mathrm{C}$. Specimens were subjected to different curing conditions: wet (immersed) and dry (air conditions). They concluded that smaller ceramic particles heat treated at $1000^{\circ} \mathrm{C}$ improved air lime mortar strength and that, in the long term, the immersed specimens had higher strength, which, in some measure, confirmed the hydraulic behaviour of air lime mortars with heat treated clays.

Charola et al. [59] used SEM and thermal analysis to characterize the presence of hydraulic components resulting from pozzolanic reactions in air lime-pozzolan mortars. One of the pozzolans was a heat treated powder used as a raw material to produce ceramic firebricks [47]: the raw material was heated at $800^{\circ} \mathrm{C}$ for 3.5 hours and naturally cooled to room temperature. The presence of hydraulic components was highlighted by the shoulder observed on the DTG curve (corresponding to the dehydration of the calcium silicate hydrates formed) in the $600^{\circ} \mathrm{C}$ range and by the broad endothermic reaction around $500^{\circ} \mathrm{C}$. SEM examination showed the presence of newly formed crystal growths whose abundance and size correlated semi-quantitatively with the mechanical performance of the mortars. For moist curing at $95 \%$ relative humidity $(\mathrm{RH})$ and compared with $50 \% \mathrm{RH}$, the growth of the $\mathrm{CSH}$ crystals resulted in some few larger 
fibrous crystal clumps with smaller growth beginning at the surface of the heated clayish particles. The previously treated clayish pozzolan, heated at $800^{\circ} \mathrm{C}$ for 3.5 hours, was used for mortar characterization, together with similar pozzolans heat treated at $600^{\circ} \mathrm{C}$ for 3.5 hours and at $700^{\circ} \mathrm{C}$ for 0.5 hours $[29,47]$. Moropoulou et al. [60] developed an interesting laboratory study that consisted of producing and assessing the long-term mechanical behaviour and thermal analysis of hydrated air lime powder, air lime putty and natural hydraulic lime mortars. All mortars contained sand and crushed brick aggregate and a variable binder. Earth of Milos and brick powder were the pozzolans added to the binder. All mortars, except those with natural hydraulic lime and lime putty with natural pozzolanic addition, exhibited signs of incomplete carbonation even after 15 months of curing.

Bakolas et al. [5] studied hydrated air lime pastes with ceramic powder in three different ceramic powder/lime ratios to evaluate the pozzolanicity of ceramic powder. Handmade ceramic brick heat treated at temperatures below $900 \stackrel{\circ}{\mathrm{C}}$ was used, and pastes were studied 270 days after curing. Analysis with differential thermal analysis and thermogravimetry, $\mathrm{XRD}$, strength tests and mercury intrusion porosimetry tests showed that the initial amount of hydrated lime was not totally consumed after 270 days and that the consumed lime increased for greater ceramic powder/lime ratios. Furthermore, with the increase in the ceramic powder/lime ratio, total pore volume decreased and the pore size also reduced.

Matias et al. [36] produced air lime mortars with grain and brick dust and evaluated their compressive and flexural strength, dynamic modulus of elasticity, water vapour permeability and water absorption by capillarity action, for varying volumetric proportions of the constituents. The authors reported that all mortars had values considered acceptable for conservation and rehabilitation purposes.

Budak et al. [33] analysed the influence of the calcination temperature of clays added to air lime mortars on their behaviour. Clays heated at temperatures of $400^{\circ} \mathrm{C}, 450^{\circ} \mathrm{C}, 500^{\circ} \mathrm{C}, 550^{\circ} \mathrm{C}, 600^{\circ} \mathrm{C}, 800^{\circ} \mathrm{C}$ and $1200^{\circ} \mathrm{C}$ at a heating rate of $10^{\circ} \mathrm{C} / \mathrm{min}$ were tested. They ascertained that clays heat treated at temperatures between $500^{\circ} \mathrm{C}$ and $700^{\circ} \mathrm{C}$ acted positively and developed pozzolanic reactivity.

Veiga et al. [61] studied lime-based mortars for the rehabilitation of old buildings and developed several compositions with air lime, hydraulic lime and air lime-cement and some pozzolans, including brick powder. Laboratory and in situ characterization was performed. The same researchers established in previous studies some requirements based on the characterization of pre-existing mortar. Therefore, they were able to compare their results with the requirements they had established and add to the knowledge of these mortars. 
Vejmelková et al. [62] prepared air-lime mortars with fired Czech clay shale, a common product in Central Europe, and compared the results with a lime-metakaolin mortar and a commercial renovation mortar. The clay shale was heat treated at temperatures similar to those used for metakaolin production (currently 600 $\left.900^{\circ} \mathrm{C}\right)$. After characterizing the clay shale in terms of chemistry and size, mortars were prepared and characterized in terms of density, porosity, mechanical strength, freeze/thaw resistance, water vapour permeability and thermal properties. The mechanical properties and frost resistance results were improved by including clay shale, and both water vapour diffusion and water absorption values were lower than those of the reference and metakaolin mortars. These results might be related to the fineness of clay particles. In general, the performance of these mortars was quite appropriate for rehabilitation purposes.

Table 1 summarizes all the heating temperatures and the thermal treatments that the researchers mentioned above found to be appropriate for developing a pozzolanic reaction, whenever indicated.

Table 2 and Table 3 summarize the most relevant characteristics obtained for new cement and lime mortars, respectively, along with the fine fraction of heat treated clays. Proportions refer to volume whenever not defined.

Table 1: Heating temperatures and thermal treatments considered as pozzolanic enhancer

\begin{tabular}{|c|c|c|}
\hline Author(s), year & Temperature $\left[{ }^{\circ} \mathrm{C}\right]$ & Thermal treatment \\
\hline Teutonico et al., 1994 [57] & 950 & --- \\
\hline He et al., 1995 [51] & $650-930$ & --- \\
\hline Al-Rawas et al., 1998 [26] & $730-850$ & $30 \mathrm{~min} / 60 \mathrm{~min}$ \\
\hline Cortina et al., 2002 [58] & 1000 & --- \\
\hline $\begin{array}{l}\text { Faria-Rodrigues and } \\
\text { Henriques, } 2004 \text { [35] }\end{array}$ & $600-900$ & Old roof tiles production \\
\hline Böke et al., 2006 [8] & $450-800$ & --- \\
\hline Chakchouk et al., 2006 [49] & 700 & For $5 \mathrm{~h}$ \\
\hline O'Farrell et al., 2006 [25] & 800 & $\begin{array}{l}\text { Heating in crucibles to } 800^{\circ} \mathrm{C} \text { with a } \\
\text { heating ramp of } 100^{\circ} \mathrm{C} \text { per hour. } \\
\text { Furnace environment was kept at that } \\
\text { temperature for } 2 \mathrm{~h} \text {. }\end{array}$ \\
\hline Velosa, 2006 [43] & $750-800$ & For $2 \mathrm{~h}$ \\
\hline Faria-Rodrigues, 2009 [29] & $600,700,800$ & $\begin{array}{c}\text { For } 0.5 \mathrm{~h}\left(700^{\circ} \mathrm{C}\right) \text { and for } 3.5 \mathrm{~h}\left(600^{\circ} \mathrm{C}\right. \\
\left.\text { and } 800^{\circ} \mathrm{C}\right)\end{array}$ \\
\hline Lavat et al., 2009 [55] & $890-1000$ & $24 \mathrm{~h}-30 \mathrm{~h}$ in a tunnel kiln \\
\hline Budak et al., 2010 [33] & $500-700$ & Heating rate of $10^{\circ} \mathrm{C} / \mathrm{min}$ \\
\hline $\begin{array}{l}\text { Pereira-de-Oliveira et al., } \\
2012[56]\end{array}$ & $1100-1200$ & Calcinated in a tunnel kiln \\
\hline
\end{tabular}


Table 2: Most relevant characteristics of cement mortars with fine fraction of heat treated clays

\begin{tabular}{|c|c|c|c|}
\hline $\begin{array}{l}\text { Author(s), } \\
\text { year }\end{array}$ & $\begin{array}{c}\text { Studied } \\
\text { compositions }\end{array}$ & Clay & Main findings \\
\hline $\begin{array}{l}\text { He C et al., } \\
1995 \text { [51] }\end{array}$ & $\begin{array}{c}\text { 70:30:300 } \\
\text { (binder:clay:sand) } \\
\text { Proportions by } \\
\text { weight. }\end{array}$ & $\begin{array}{l}\text { Six different } \\
\text { clays heat } \\
\text { treated at } \\
\text { optimum } \\
\text { temperatures } \\
\text { and raw } \\
\text { clays }\end{array}$ & $\begin{array}{l}\text { - Mortars with Ca-montmorillonite, kaolinite, Na- } \\
\text { montmorillonite and mixed-layer clays heat } \\
\text { treated at optimum temperatures increase } \\
\text { compressive strength in } 112 \%-130 \% \text {, when } \\
\text { compared with reference cement mortar. } \\
\text { - Mortars with Illite and Sepiolite mortars lie at } \\
\text { about } 80 \%-84 \% \text { of the reference mortar } \\
\text { strength at the optimum calcination } \\
\text { temperatures. } \\
\text { - Heat treatment of the clays significantly } \\
\text { increases mortars strength. }\end{array}$ \\
\hline $\begin{array}{l}\text { O'Farrell et } \\
\text { al., 2003 [52] }\end{array}$ & $\begin{array}{l}1: 3 \text { (binder:sand) } \\
\text { Cement partially } \\
\text { replaced by } 0 \% \text {, } \\
10 \%, 20 \% \text { and } 30 \% \\
\text { of clay. }\end{array}$ & $\begin{array}{l}\text { ground bricks } \\
\text { with different } \\
\text { origins }\end{array}$ & $\begin{array}{l}\text { - For shorter curing periods the increase of brick } \\
\text { content increases intruded pore volume, } \\
\text { reduces the amount of small pores and reduces } \\
\text { compressive strength. } \\
\text { - For longer curing periods results approach } \\
\text { from the control mortar. }\end{array}$ \\
\hline $\begin{array}{l}\text { O'Farrell et } \\
\text { al., } 2006 \text { [25] }\end{array}$ & $\begin{array}{l}1: 3 \text { (binder:sand) } \\
\text { Cement partially } \\
\text { replaced by } 0 \% \text {, } \\
10 \%, 20 \% \text { and } 30 \% \\
\text { for clays. }\end{array}$ & $\begin{array}{l}\text { ground waste } \\
\text { clay bricks or } \\
\text { heat-treated } \\
\text { brick clays }\end{array}$ & $\begin{array}{l}\text { - Replacements up to } 20 \% \text { give strengths at } 90 \\
\text { days that are the same as or greater than the } \\
\text { control mortar. } \\
\text { - Ground brick mortars provide better strength } \\
\text { performance at extended ages. } \\
\text { - Heat-treated brick clays give superior } \\
\text { performance in what concerns to sulfate } \\
\text { resistance. } \\
\text { - Heat-treated clay mortars reduce the } \\
\text { expansion due to exposure to synthetic } \\
\text { seawater. }\end{array}$ \\
\hline $\begin{array}{l}\text { Toledo Filho } \\
\text { et al., 2007 } \\
\text { [53] }\end{array}$ & $\begin{array}{l}\text { 1:1.5 (binder:sand) } \\
\text { Proportions by } \\
\text { weight. } \\
\text { Cement partially } \\
\text { replaced by } 0 \% \text { to } \\
40 \% \text { of clay }\end{array}$ & $\begin{array}{l}\text { ground } \\
\text { crushed brick } \\
\text { waste }\end{array}$ & $\begin{array}{l}\text { - The use of ground brick reduced the chloride } \\
\text { ion penetration and the tensile strength loss of } \\
\text { the control mortars exposed to a } 5 \% \text { magnesium } \\
\text { sulfate solution. } \\
\text { - Until } 20 \% \text { of cement replacement ground brick } \\
\text { had almost no influence on the compressive } \\
\text { strength and elastic modulus. }\end{array}$ \\
\hline $\begin{array}{l}\text { Pereira-de- } \\
\text { Oliveira et } \\
\text { al., } 2012[56]\end{array}$ & $\begin{array}{l}1: 3 \text { (binder:sand) } \\
\text { Cement partially } \\
\text { replaced by } 0 \% \text {, } \\
10 \%, 20 \%, 25 \% \text {, } \\
30 \% \text { and } 40 \% \text { of } \\
\quad \text { clay. }\end{array}$ & $\begin{array}{l}\text { brick and tile } \\
\text { waste }\end{array}$ & $\begin{array}{l}\text { - Mortars with cement replacement by tile and } \\
\text { brick powders satisfy the minimum strength } \\
\text { activity index at } 28 \text { days. }\end{array}$ \\
\hline
\end{tabular}


Table 3: Most relevant characteristics of lime mortars with fine fraction of heat treated clays

\begin{tabular}{|c|c|c|c|c|}
\hline $\begin{array}{c}\text { Author(s), } \\
\text { year }\end{array}$ & Studied compositions & Lime & Clay & Main findings \\
\hline $\begin{array}{l}\text { Teutonico } \\
\text { et al., } \\
1994^{*}[57]\end{array}$ & $\begin{array}{c}1: 3 \text { (lime:sand) } \\
\text { 1:3:1 (lime:sand:clay) } \\
\text { 1:2.5:1 (lime:sand:clay) } \\
\text { 1:2.5:0.5 (lime:sand:HTBD) } \\
\text { ( }{ }^{\star} \text { Cement compositions were also } \\
\text { studied) }\end{array}$ & $\begin{array}{l}\text { hydrated } \\
\text { lime, } \\
\text { lime } \\
\text { putty } \\
\text { and } \\
\text { hydraulic } \\
\text { lime }\end{array}$ & $\begin{array}{l}\text { brick powder } \\
\text { HTBD - high } \\
\text { temperature } \\
\text { insulant } \\
\text { refractory } \\
\text { brick dust. }\end{array}$ & $\begin{array}{l}\text { - The addition of brick dust } \\
\text { significantly changes the properties of } \\
\text { lime mortars. } \\
\text { - Low-fired brick dust has the most } \\
\text { positive effect on the strength and } \\
\text { durability of lime mixtures. }\end{array}$ \\
\hline $\begin{array}{l}\text { Al-Rawas } \\
\text { et al., } 1998 \\
{[26]}\end{array}$ & $\begin{array}{c}\text { 1:0.33:0.67 (clay:lime:sand) } \\
\text { Proportions by weight. }\end{array}$ & $\begin{array}{l}\text { hydrated } \\
\text { lime }\end{array}$ & $\begin{array}{c}\text { several clays } \\
\text { with different } \\
\text { heat } \\
\text { treatments } \\
\end{array}$ & $\begin{array}{l}\text { - The compressive strength tests } \\
\text { showed the superiority of sarooj } \\
\text { produced from Al-Hamra as compared } \\
\text { with the other sites. }\end{array}$ \\
\hline $\begin{array}{l}\text { Cortina et } \\
\text { al., 2002 } \\
\text { [58] }\end{array}$ & $\begin{array}{c}\text { 1:1.5:2 (lime:clay:sand) } \\
1: 1.5 \text { (lime:clay) } \\
1: 2 \text { (lime:clay) } \\
1: 2.5 \text { (lime:clay) } \\
1: 3 \text { (lime:clay) } \\
\text { Proportions by weight. } \\
\text { Water ratios of } 1,1.1,1.2,1.3 \text { and } \\
1.4 .\end{array}$ & $\begin{array}{l}\text { hydrated } \\
\text { lime }\end{array}$ & $\begin{array}{l}\text { Chamotte } \\
\text { powder } \\
\text { (burnt clay } \\
\text { from the } \\
\text { ceramic } \\
\text { industry } \\
\text { waste) }\end{array}$ & 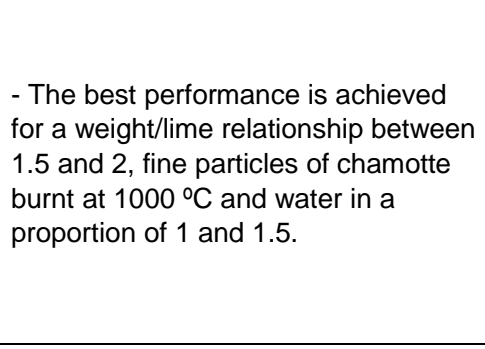 \\
\hline $\begin{array}{l}\text { Charola et } \\
\text { al., 2005 } \\
\text { [59] }\end{array}$ & 1:1:4 (lime:clay:sand) & $\begin{array}{l}\text { hydrated } \\
\text { lime }\end{array}$ & $\begin{array}{l}\text { ceramic } \\
\text { powder from } \\
\text { heat treated } \\
\text { raw ceramic } \\
\text { firebricks }\end{array}$ & $\begin{array}{l}\text { - Mortars show improved mechanical } \\
\text { characteristics, except for mortars with } \\
\text { clayish material fired at low } \\
\text { temperature for a short period }\left(700^{\circ} \mathrm{C}\right. \\
\text { - } 0.5 \text { hours). } \\
\text { - The resistance to chlorides and } \\
\text { sulfates attack is improved by ceramic } \\
\text { powder. }\end{array}$ \\
\hline $\begin{array}{l}\text { Faria- } \\
\text { Rodrigues, } \\
2005[74]\end{array}$ & $\begin{array}{l}\text { 1:0.5:3 (lime:clay:sand) } \\
\text { 1:1.5:5 (lime:clay:sand) } \\
\text { Lime: hydrated lime } \\
\text { Clay: Ceramic powder }\end{array}$ & $\begin{array}{l}\text { hydrated } \\
\text { lime }\end{array}$ & $\begin{array}{l}\text { ceramic } \\
\text { powder }\end{array}$ & $\begin{array}{l}\text { - Mortars with clays heat treated for } \\
\text { longer periods have higher and more } \\
\text { suitable mechanical strength and all } \\
\text { mortars with clays had satisfactory } \\
\text { results for resistance to chlorides. }\end{array}$ \\
\hline $\begin{array}{l}\text { Moropoulou } \\
\text { et al., 2005 } \\
\text { [60] }\end{array}$ & $\begin{array}{l}\text { 1:1:2 (lime:clay:sand) } \\
\text { Proportions by weight. }\end{array}$ & $\begin{array}{l}\text { lime } \\
\text { putty } \\
\text { and } \\
\text { hydrated } \\
\text { lime }\end{array}$ & $\begin{array}{l}\text { ceramic } \\
\text { powder }\end{array}$ & $\begin{array}{l}\text { - Mortars with powdered air lime and } \\
\text { brick powder have the best } \\
\text { mechanical behaviour with a low } \\
\text { compressive and flexural strength } \\
\text { ratio, an indicator of a low elastic } \\
\text { modulus, which is a favourable } \\
\text { condition for restoration mortars. }\end{array}$ \\
\hline $\begin{array}{l}\text { Velosa, } \\
2006 \text { [43] }\end{array}$ & $\begin{array}{c}1: 1: 4 \text { (lime(1):clay(3): sand) } \\
1: 1: 2.5 \text { (lime(1):clay(4):sand) } \\
1: 1: 1 \text { (lime(2):clay(4):sand) }\end{array}$ & $\begin{array}{l}(1) \\
\text { hydrated } \\
\text { lime and } \\
\text { (2) lime } \\
\text { putty }\end{array}$ & $\begin{array}{l}\text { (3) brick } \\
\text { powder and } \\
\text { (4) brick } \\
\text { grains }\end{array}$ & $\begin{array}{l}\text { - Brick dust eases drying process, } \\
\text { reduces water absorption by capillary } \\
\text { action and decreases shrinkage. } \\
\text { - Brick fragments increase flexural } \\
\text { strength. }\end{array}$ \\
\hline $\begin{array}{l}\text { Bakolas et } \\
\text { al., } 2008 \text { [5] }\end{array}$ & $\begin{array}{c}1 \text { (clay/lime) } \\
2 \text { (clay/lime) } \\
3 \text { (clay/lime) } \\
\text { Clay/lime weight ratios. }\end{array}$ & $\begin{array}{l}\text { hydrated } \\
\text { lime }\end{array}$ & $\begin{array}{l}\text { ceramic } \\
\text { powder }\end{array}$ & $\begin{array}{l}\text { - The consumed lime increases for } \\
\text { higher ceramic powder/lime ratios } \\
\text { which is confirmed by compressive } \\
\text { strength results. }\end{array}$ \\
\hline $\begin{array}{l}\text { Matias et } \\
\text { al., } 2008 \\
{[36]}\end{array}$ & $\begin{array}{c}1: 3 \text { (lime:sand) } \\
1: 4 \text { (cement:sand) } \\
\text { 1:0.5:3 (lime:clay(1):sand) } \\
1: 0.5: 1: 2 \text { (lime:clay(1):clay(2):sand) } \\
1: 6 \text { (lime:sand) } \\
1: 5.3 \text { (cement:sand) } \\
\text { 1:0.6:6 (lime:clay(1):sand) } \\
1: 0.6: 1.4: 4 \\
\text { (lime:clay(1):clay(2):sand) } \\
\text { Proportions by weight. }\end{array}$ & $\begin{array}{l}\text { quick } \\
\text { lime }\end{array}$ & $\begin{array}{l}\text { (1) Brick } \\
\text { powder and } \\
\text { (2) brick } \\
\text { grains }\end{array}$ & $\begin{array}{l}\text { - Mortars with 1:0.6:6 have improved } \\
\text { mechanical behaviour. } \\
\text { - Despite the presence of ceramic } \\
\text { dust worsen some aspects of mortars' } \\
\text { behaviour, all mortars had values } \\
\text { considered acceptable for } \\
\text { conservation and rehabilitation } \\
\text { purposes. }\end{array}$ \\
\hline
\end{tabular}




\begin{tabular}{|c|c|c|c|l|}
\hline $\begin{array}{c}\text { Budak et } \\
\text { al., 2010 } \\
{[33]}\end{array}$ & $\begin{array}{c}\text { With 1/2 heat treated clay/aggregate } \\
\text { ratio and heating temperatures of } \\
25^{\circ} \mathrm{C}, 600^{\circ} \mathrm{C} \text { and } 1000^{\circ} \mathrm{C} .\end{array}$ & $\begin{array}{c}\text { hydrated } \\
\text { lime }\end{array}$ & $\begin{array}{c}\text { Clay with } \\
\text { different } \\
\text { heating } \\
\text { temperatures }\end{array}$ & $\begin{array}{l}- \text { The samples containing clay } \\
\text { thermally treated at } 600^{\circ} \mathrm{C} \text { gain higher } \\
\text { compressive strength values } \\
\text { compared to the other clay samples. }\end{array}$ \\
\hline $\begin{array}{c}\text { Veiga et al., } \\
2010 \text { [61] }\end{array}$ & $\begin{array}{c}1: 1: 4 \text { (lime:clay:sand) } \\
\text { hydrated } \\
\text { lime }\end{array}$ & $\begin{array}{l}- \text { The studied composition containing } \\
\text { brick dust fulfils the requirements for } \\
\text { mechanical strength and air thickness } \\
\text { of equivalent diffusion, despite } \\
\text { capillary coefficient result is above the } \\
\text { defined range. }\end{array}$ \\
\hline $\begin{array}{c}\text { Vejmelková } \\
\text { et al., 2012 } \\
\text { [62] }\end{array}$ & $\begin{array}{c}2.5: 7.5 \text { (lime:sand) } \\
\text { brick powder }\end{array}$ & hydrated \\
lime & $\begin{array}{c}\text { Burnt clays } \\
\text { with three } \\
\text { different } \\
\text { particle size } \\
\text { distributions }\end{array}$ & $\begin{array}{l}\text { - Burnt clay improves the mechanical } \\
\text { properties and frost resistance. } \\
\text { - Water vapour diffusion and water } \\
\text { absorption values are lower than } \\
\text { those of the reference mortar. }\end{array}$ \\
\hline
\end{tabular}

\section{Air lime mortars with ceramic fragments as aggregate}

Included in lime mortars in granular form, ceramic elements might give rise to mechanisms related to the cohesive structure of mortar, which have not yet been fully studied. Under these circumstances, ceramic aggregate may potentiate binder-aggregate cohesion through a kind of pozzolanic reaction which occurs in the interface between the binder and the aggregate and within porous structure of the aggregate [8].

The studies mentioned in section 4 give some examples of old mortars that contain coarse ceramic fragments, which are summarized in Table 4.

Table 4: Old mortars with coarse ceramic fragments

\begin{tabular}{|c|c|}
\hline Researchers, Year & Significant findings \\
\hline Moropoulou et al., 1995 [18] & $\begin{array}{c}\text { Mortars designated "crushed brick mortars" in which } \\
\text { reaction products were detected at the brick fragment-lime } \\
\text { interface (were classified as "pozzolanic mortars") }\end{array}$ \\
\hline $\begin{array}{c}\text { Maravelali-Kalaitzaqui et al., } \\
\text { 2003 [32] }\end{array}$ & $\begin{array}{c}\text { Mortars that contained coarse aggregate from crushed brick } \\
\text { with clear hydraulic properties }\end{array}$ \\
\hline $\begin{array}{c}\text { Moropoulou et al., 2000, 2003 } \\
\text { and 2005 [2,30,31] }\end{array}$ & $\begin{array}{c}\text { Ceramic residues used in ancient mortars that also worked } \\
\text { as an aggregate substitute, providing mortars some } \\
\text { lightness and waterproofing capacity (mentioning the } \\
\text { example of Hagia Sophia mortars) }\end{array}$ \\
\hline $\begin{array}{c}\text { Santos-Silva et al., 2006 [11] } \\
\text { Santos-Silva et al., 2006 [12] }\end{array}$ & $\begin{array}{c}\text { Mortars with brick fragments whose grain sizes reached 5 } \\
\text { mm, with reaction products in the microstructure that } \\
\text { suggested pozzolanic reactions }\end{array}$ \\
\hline Böke et al., 2006 [8] & $\begin{array}{c}\text { Mortars that contained high amounts of crushed ceramics, } \\
\text { in dust and coarser forms, with high amounts of pozzolanic } \\
\text { indeed, all over the binder and dissolved into the lime }\end{array}$ \\
\hline Velosa et al., 2007 [13] & $\begin{array}{c}\text { Larger particles from brick milling in mortars with clear signs } \\
\text { of pozzolanic reaction }\end{array}$ \\
\hline Ugurlu and Böke, 2009 [17] & $\begin{array}{c}\text { Mortars with brick fragments whose particle sizes were } \\
\text { similar to those of aggregates }\end{array}$ \\
1.18 mm were the main aggregate fraction
\end{tabular}




\begin{tabular}{|c|c|}
\hline Borsoi et al., 2010 [9] & $\begin{array}{c}\text { Mortars with ceramic and brick residues in a granular form } \\
\text { and with the occurrence of rims around brick fragments, } \\
\text { arising from pozzolanic reactions with the binder }\end{array}$ \\
\hline Cardoso et al., 2013 [34] & $\begin{array}{c}\text { Ceramic fragment mortars with different grain sizes whose } \\
\text { sample with larger ceramic fragments exhibited a higher } \\
\text { hydraulicity factor }\end{array}$ \\
\hline
\end{tabular}

Several studies were carried out to understand the specific reactivity of ceramic fragments as aggregates in mortars. For instance, Baronio et al. [3] analysed the complex working system of historical mortars from the Byzantine period, with brick fragments, and studied their possible pozzolanic reactions. These mortars contained brick aggregates of significant sizes. Despite the fact that these composites had quite a low specific surface area, in some of the examples they were able to detect a clear reaction at the binderaggregate surface, in the interface and in the pores of the structural mortars, which contributed to the cohesion of the materials. Researchers have tried to reproduce similar mortars in a laboratory environment and found low pozzolanic reactivity and a slow carbonation process, as expected. However, in general, over the long term, the reproduced mortars yielded promising results.

Faria-Rodrigues and Henriques [35] crushed ceramic roof tiles and used them in the form of dust and small grains in air lime mortars, as a partial replacement of river sand. They characterized several mortars to assess their compatibility as repair mortars for old masonry.

Cortina et al. [58] prepared mortars with ceramic grains and determined that these did not affect mechanical strength, and therefore might be seen as good substitutes for common sand.

Some of the mortars developed by Matias et al. [36] contained brick grain to replace the aggregate (coarser fraction of the milled brick was separated from finer particles) and these mortars had quite a satisfactory mechanical and physical behaviour. The same researchers used grain and dust fractions altogether as sand substitution [37] and verified that air lime mortars with higher percentages of residue and natural hydraulic lime mortars with lower percentage of residues reached a quite satisfactory mechanical performance. When compared with reference values [61], global behaviour appear to be well adjusted for repair and substitution mortars.

Table 5 summarizes the most relevant characteristics obtained when using coarse fraction of heat treated clays to substitute aggregates in mortars. Proportions refer to volume unless defined otherwise.

Table 5: Most relevant characteristics of mortars with coarse fraction of heat treated clays

\begin{tabular}{|c|c|c|c|l|}
\hline $\begin{array}{c}\text { Author(s), } \\
\text { year }\end{array}$ & Studied compositions & Binder & Clay & Main findings \\
\hline $\begin{array}{c}\text { Baronio et } \\
\text { al., 1997 [3] }\end{array}$ & $1: 3$ (lime:aggregate) & $\begin{array}{c}\text { hydrated } \\
\text { lime }\end{array}$ & brick grains & $\begin{array}{l}\text { - Reactions in the binder-aggregate } \\
\text { intere are observed. } \\
\text { - Mortars present satisfactory bulk density }\end{array}$ \\
\hline
\end{tabular}




\begin{tabular}{|c|c|c|c|c|}
\hline & grains $(20.8 \%)$ & & & $\begin{array}{l}\text { and deformability results after a long } \\
\text { curing period. }\end{array}$ \\
\hline $\begin{array}{l}\text { Silva et al., } \\
2009 \text { [54] }\end{array}$ & $\begin{array}{l}1: 4 \text { (cement:sand) } \\
\text { Aggregate partially replaced by } 0 \%, 5 \% \\
\text { and } 10 \% \text { of red clay brick grains. }\end{array}$ & $\begin{array}{l}\text { Portland } \\
\text { cement }\end{array}$ & $\begin{array}{l}\text { red brick } \\
\text { grains }\end{array}$ & $\begin{array}{l}\text { - A } 10 \% \text { replacement improves mortars } \\
\text { performance when considering its use as } \\
\text { a rendering mortar, with exception of } \\
\text { shrinkage and water vapour permeability. }\end{array}$ \\
\hline $\begin{array}{l}\text { Cortina et } \\
\text { al., } 2002 \\
{[58]}\end{array}$ & $\begin{array}{c}\text { 1:0.5:3 (lime:clay:sand) } \\
1: 0.5: 2 \text { (lime:clay:sand) } \\
\text { 1:0.5 (lime:clay) } \\
1: 1: 3 \text { (lime:clay:sand) } \\
1: 1: 2 \text { (lime:clay:sand) } \\
1: 1: 0 \text { (lime:clay) } \\
1: 1.5: 3 \text { (lime:clay :sand) } \\
1: 1.5: 2 \text { (lime:clay) } \\
1: 1.5 \text { (lime:clay) } \\
\text { Proportions by weight. } \\
\text { Water ratios of } 1,1.1,1.2 \text { and 1.3. }\end{array}$ & $\begin{array}{l}\text { hydrated } \\
\text { lime }\end{array}$ & $\begin{array}{l}\text { Chamotte } \\
\text { grains (burnt } \\
\text { clay from the } \\
\text { ceramic } \\
\text { industry } \\
\text { waste) }\end{array}$ & $\begin{array}{l}\text { - Evidences of pozzolanic activity are not } \\
\text { reached for mortars with chamotte coarse } \\
\text { particles. } \\
\text { - Chamotte does not affect mechanical } \\
\text { strength, and so it may be seen as a good } \\
\text { substitute for common sand. }\end{array}$ \\
\hline $\begin{array}{c}\text { Moropoulou } \\
\text { et al., 2005 } \\
\text { [60] }\end{array}$ & $\begin{array}{l}\text { 1:2.3 (lime:aggregates) } \\
\text { Proportions by weight. } \\
\text { Aggregates: mixed sand }(0-1 \mathrm{~mm}) \text { and } \\
\text { ground brick }(1-6 \mathrm{~mm}) .\end{array}$ & $\begin{array}{l}\text { hydraulic } \\
\text { lime }\end{array}$ & ground brick & $\begin{array}{l}\text { - Mortar with crushed brick acquires } \\
\text { quasi-maximum strength within the first } \\
\text { month, with no significant variations of } \\
\text { compressive strength afterwards. } \\
\text { - Mortars present a low compressive and } \\
\text { flexural strength ratio, which indicates a } \\
\text { lower elastic modulus, a favourable } \\
\text { condition for repair and substitution } \\
\text { mortars. }\end{array}$ \\
\hline $\begin{array}{l}\text { Matias et } \\
\text { al., } 2008 \\
{[36]}\end{array}$ & $\begin{array}{c}1: 3 \text { (lime:sand) } \\
1: 4 \text { (cement:sand) } \\
1: 1: 2 \text { (lime:clay(2):sand) } \\
1: 0.5: 1: 2 \text { (lime:clay(1):clay(2):sand) } \\
1: 6 \text { (lime:sand) } \\
1: 5.3 \text { (cement:sand) } \\
1: 1.4: 4 \text { (lime:clay(2):sand) } \\
1: 0.6: 1.4: 4 \text { (lime:clay(1):clay(2):sand) } \\
\text { Proportions by weight. }\end{array}$ & $\begin{array}{l}\text { quick } \\
\text { lime }\end{array}$ & $\begin{array}{l}\text { (1) brick } \\
\text { powder and } \\
\text { (2) brick } \\
\text { grains }\end{array}$ & $\begin{array}{l}\text { - Mortars with } 1: 1.4: 4 \text { show improved } \\
\text { mechanical behaviour. } \\
\text { - Despite the presence of coarse grains } \\
\text { worsen some aspects of mortars' } \\
\text { behaviour, all mortars have values } \\
\text { considered acceptable for conservation } \\
\text { and rehabilitation purposes. }\end{array}$ \\
\hline $\begin{array}{l}\text { Faria- } \\
\text { Rodrigues } \\
\quad \text { and } \\
\text { Henriques, } \\
2004 \text { [35] }\end{array}$ & $\begin{array}{c}1: 3 \text { (lime:sand) } \\
1: 1: 2 \text { (lime:clay:sand) } \\
1: 0.5: 2.5 \text { (lime:clay:sand) }\end{array}$ & $\begin{array}{l}\text { hydrated } \\
\text { lime }\end{array}$ & $\begin{array}{l}\text { grains from } \\
\text { old tiles }\end{array}$ & $\begin{array}{l}\text { - The mortars present a low density and } \\
\text { high open porosity, in accordance with the } \\
\text { percentage of crushed tiles used. } \\
\text { - Compared to lime mortars, lime-tile } \\
\text { mortars have lower density and higher } \\
\text { open porosity. } \\
\text { - } 1: 1: 2 \text { mortar presents lower capillary } \\
\text { coefficient and a higher asymptotic value } \\
\text { of water absorption and the } 1: 0.5: 2.5 \\
\text { mortar exhibited the opposite behaviour. } \\
\text { - Mechanical behaviour improves with the } \\
\text { increase of tiles grains. } \\
\text { - Resistance to chlorides improves with } \\
\text { the increase of tiles grains, which might } \\
\text { be explained by the mechanical strength } \\
\text { results combined with the higher open } \\
\text { porosity. }\end{array}$ \\
\hline $\begin{array}{l}\text { Matias et } \\
\text { al., } 2013 \\
\text { [37] }\end{array}$ & $\begin{array}{c}1: 3 \text { (lime:sand) } \\
\text { 1:0.6:2.4 (lime:clay:sand) } \\
\text { 1:1.2:1.8 (lime:clay:sand) }\end{array}$ & $\begin{array}{l}\text { hydrated } \\
\text { lime and } \\
\text { natural } \\
\text { hydraulic } \\
\text { lime }\end{array}$ & $\begin{array}{l}\text { crushed } \\
\text { bricks, tiles } \\
\text { and pottery }\end{array}$ & $\begin{array}{l}\text { - Ceramic waste increases mechanical } \\
\text { strength. Air lime mortars with high waste } \\
\text { proportion and natural hydraulic lime } \\
\text { mortars with low waste proportion present } \\
\text { a better performance. } \\
\text { - Water absorption increases and water } \\
\text { vapour permeability decreases with the }\end{array}$ \\
\hline
\end{tabular}




\begin{tabular}{|l|l|l|l|}
\hline & & & $\begin{array}{l}\text { presence of ceramic waste. However, } \\
\text { differences for the reference mortars are } \\
\text { not significant. }\end{array}$ \\
\hline
\end{tabular}

\section{Advantages of the use of ceramic waste in repair mortars}

\subsection{Environmental impact caused by ceramic waste disposal}

As mentioned, most ceramics factories waste a significant portion of the final product due to quality requirements. This is observed in ceramic brick and roof tile producers, for example, whose raw materials are mainly clay and silica. Prepared clay-based pastes are submitted to heat treatment in high temperature furnaces and the final products often have small defects, such as cracking and warping, which make the product unfit for marketing. However, although some factories are ready to reintroduce some defective materials into the production line, this waste is usually sent to landfill. Seldom, small portions are sold for other purposes such as for paving sports facilities. The nature and characteristics of ceramic waste acquired during heat treatment (especially hardness) makes its treatment and disposal difficult. It is therefore very important to find solutions that allow this waste to be reused by reintroducing it into production.

The European Pollutant Release and Transfer Register [63] indicates that in Europe, in 2012 the manufacturers of tiles, bricks, stoneware and porcelain generated about 2588120 tonnes of non-hazardous waste, $9.3 \%$ of which was not recovered. The percentage may be low but it still represents 239954 tonnes of waste per year. This also happen in other continents: in Argentina, for example, Lavat et al. [55] mentioned that $2 \%$ of the final product of local ceramics factories was waste. In Portugal, an important decorative ceramics producer of pottery and façade tiles, the most common destination is also landfill disposal. In the specific case of plants in the central region of Portugal, the last data found, which remounts to 2003 , refers that $96 \%$ of waste in ceramics factories came from the production process and about $37 \%$ of that waste corresponded to heat treated products, whose destination would be landfill disposal [64]. Another well-known source of ceramic waste is construction and demolition waste (CDW). When properly sorted from other materials, ceramic tiles and brick waste from building construction and demolition may be a profitable resource for the design of mortars and concretes [65-72].

\subsection{The significant benefits of reusing ceramic waste}

Many countries have urgent needs for correct conservation and rehabilitation practices, namely for the repair of existent masonry wall coatings. A major part of those coatings are rendering (applied in the exterior 
surface of walls) and plastering (in the interior surface of walls) systems. For that reason, large quantities of mortars will have to be produced.

From the environmental standpoint, the use of ceramic waste offers advantages that go beyond the reutilization and consequent reduction of landfill disposal.

When introduced in mortars as fine particles (dust), waste may play the role of at least slightly pozzolanic materials, and so they can help to reduce the amount of binder needed for the mixtures. Therefore, it is possible to significantly reduce the use and production of binders, which would have many positive advantages for the environment. Not only will fewer raw materials have to be extracted, but energy consumption and $\mathrm{CO}_{2}$ emissions will also decrease. According to the Intergovernmental Panel on Climate Change Report, $\mathrm{CO}_{2}$ emissions due to fossil fuels consumption and cement production increased at a $3.2 \%$ rate, between 2000 and 2009. These emissions represent $3 / 4$ of total $\mathrm{CO}_{2}$ emissions, and $4 \%$ of them derived from cement factories [73].

Moreover, pozzolan production will soon be compromised, especially due to the demand for raw materials for the cement industry (clinker, fly ash, silica fume and natural pozzolans) and so, finding alternative pozzolanic products will become ever more relevant [56]. When used in a granular form, ceramic waste may help to reduce the consumption of natural aggregates. In the specific case of mortar, this may significantly reduce the disastrous consequences of sand extraction. Its incorporation in mortar is also advantageous in economic and energy terms [39].

Another important aspect that should be considered is the final colour of the mortars. Most of the ceramic waste available comes from clays with a reddish coloration that, when combined with light-coloured binders, yield mortars a pink-orange hue, very characteristic and similar to the ones used in old buildings. Thus, the use of these mortars as a final plaster, without other coatings, also provides economical, technical and environmental advantages.

In short, when it partially replaces binder or aggregate, ceramic waste yields economic and environmental benefits:

- it minimizes binder production, significantly reducing the associated $\mathrm{CO}_{2}$ emissions and energy consumption;

- it reduces the extraction of raw materials for binder and aggregates production, and lessens the environmental impact associated with the disruption of the landscape and riverbeds by mine workings. 
- it encourages the avoidance of using paints and other coating products when plasters with red coloured ceramics are applied.

As a product for incorporation in lime mortars aimed to repair or replace the mortar in old buildings, they might have technical advantages:

- mortars made with suitable amounts of ceramic waste may show a high degree of compatibility with old buildings masonry systems, particularly when compared to mortars with hydraulic binders;

- the mortars may exhibit superior performance when compared to pure air lime mortars, because of the hydraulic behaviour due to the potential for pozzolanic reaction of ceramic dust waste;

- ceramic waste introduced as aggregate may induce better binder/aggregate cohesion, because of the shape and composition of the fragments;

- ceramic waste may change the microstructure of air lime or natural hydraulic lime mortars (feebly hydraulic mortars), thereby improving their durability, particularly their resistance to chloride attack $[25,35,59,74]$.

\section{Conclusions}

Considering the need to produce repair and substitution mortars that are compatible with the original mortars, the knowledge of ancient solutions is extremely important. Both the characterization of old construction mortars (materials and techniques used), and the feasibility of producing similar mortars with the raw materials that are available today, are crucial. Therefore, understanding lime mortars with ceramic waste (a specific form of heat treated clays) as pozzolans, widely used in the past, is fundamental, for the rescue of these past solutions, for the development of other possible compatible mortars to use in old buildings and even for contemporary constructions whose requirements may specify the use of products with this type of characteristics.

Most of the studies developed so far are directed at cement-based mortars, so, lime mortars with ceramics produced from newer ceramic waste materials have been poorly studied as of yet. Therefore, it is considered that this assessment should be systematized, in order to justify future studies.

The present paper summarizes the main aspects related to pozzolanic reactions involving lime and thermally treated clays. Several studies developed in order to characterize the mortars used in old buildings containing ceramic dust or aggregates are also summed up. Aspects such as composition, proportion of raw materials and mechanical and physical behaviour were gathered. Their high durability also encouraged some researchers to try to reproduce these mortars under laboratory conditions. Researchers have also studied 
the pozzolanicity of heat treated clays and, more specifically, the waste from manufacturers of ceramic products or from construction and demolition.

This study has made it possible to consolidate the ideal heating temperatures required to achieve pozzolanicity and it was ascertained that most ceramics plants produce materials using temperatures close to the values reported in the studies (especially the higher ones).

Thereby, the benefits of using ceramic residues from industries to produce lime mortars compatible with old buildings systems were highlighted, as this procedure provides several important environmental, economical and technical advantages.

\section{Acknowledgments}

The authors would like to thank the FCT- Portuguese Foundation for Science and Technology for its support through the project "EXPL/ECM-COM/0928/2012 - Incorporation of ceramic residues in repair mortars". This work has also been framed under the Initiative Energy for Sustainability of the University of Coimbra and supported by the Energy and Mobility for Sustainable Regions - EMSURE - Project (CENTRO-07-0224FEDER-002004).

\section{References}

[1] Binici $\mathrm{H}$. Effect of crushed ceramic and basaltic pumice as fine aggregates on concrete mortars properties. Construction and Building Materials. 2007;21:1191-7.

[2] Moropoulou A, Bakolas A, Anagnostopoulou S. Composite materials in ancient structures. Cement and Concrete Composites. 2005;27:295-300.

[3] Baronio G, Binda L, Lombardini N. The role of brick pebbles and dust in conglomerates based on hydrated lime and crushed bricks. Construction and Building Materials. 1997;11:33-40.

[4] Vejmelková E, Keppert M, Rovnaníková P, Keršner Z, Černý R. Properties of lime composites containing a new type of pozzolana for the improvement of strength and durability. Composites Part B: Engineering. 2012;43:3534-40.

[5] Bakolas A, Aggelakopoulou E, Moropoulou A. Evaluation of pozzolanic activity and physico-mechanical characteristics in ceramic powder-lime pastes. Journal of Thermal Analysis and Calorimetry. 2008;92:34551.

[6] A. Bakolas GB, Moropoulou A, Zendri E. Characterization of structural byzantine mortars by thermogravimetric analysis. Thermochimica Acta. 1998;321:151-60. 
[7] Benedetti D, Valetti S, Bontempi E, Piccioli C, Depero LE. Study of ancient mortars from the Roman Villa of Pollio Felice in Sorrento (Naples). Applied Physics A: Materials Science \& Processing. 2004;79:341-5.

[8] Böke H, Akkurt S, İpekoğlu B, Uğurlu E. Characteristics of brick used as aggregate in historic brick-lime mortars and plasters. Cement and Concrete Research. 2006;36:1115-22.

[9] Borsoi G, Santos Silva A, Menezes P, Candeias A, Mirão J. Chemical, mineralogical and microstructural characterization of historical mortars from the Roman villa of Pisões, Beja, Portugal. Historic Mortars Conference HMC2010. Prague, Czech Republic 2010.

[10] Monteiro A, Faria-Rodrigues P. Troia Roman baths (Portugal) - Assessment of history of interventions. In: J.Delgado Rodrigues J.M.M.e., editor. International Seminar in Conservation A Tribute to Cesari Brandi. Lisbon, LNEC2006. p. 313-22.

[11] Santos-Silva A, Paiva M, Ricardo J, Salta M, Monteiro AM, Candeias AE. Characterisation of roman mortars from the archaeological site of Tróia (Portugal). Materials Science Forum. 2006;1643:514-6.

[12] Santos Silva A, Ricardo JM, Salta M, Adriano P, Mirão J, Candeias AE, Macias A. Characterization of Roman mortars from the historical town of Mertola. Heritage Weathering and Conservation. 2006;1:85-90.

[13] Velosa AL, Coroado J, Veiga MR, Rocha F. Characterisation of roman mortars from Conímbriga with respect to their repair. Materials Characterization. 2007;58:1208-16.

[14] Degryse P, Elsen J, Waelkens M. Study of ancient mortars from Sagalassos (Turkey) in view of their conservation. Cement and Concrete Research. 2002;32:1457-63.

[15] Guleç A, Tulun T. Physico-chemical and petrographical studies of old mortars and plasters of anatolia. Cement and Concrete Research. 1997;27:227-34.

[16] Lindqvist JE, Johansson S. Aggregate shape and orientation in historic mortars. 11th Euroseminar on Microscopy Applied to Building Materials. Porto, Portugal2007.

[17] Uğurlu E, Böke $\mathrm{H}$. The use of brick-lime plasters and their relevance to climatic conditions of historic bath buildings. Construction and Building Materials. 2009;23:2442-50.

[18] Moropoulou A, Bakolas A, Bisbikou K. Thermal analysis as a method of characterizing ancient ceramic technologies. Thermochimica Acta. 1995;2570:743-53.

[19] Moropoulou A, Bakolas A, Bisbikou K. Characterization of ancient byzantine and later historic mortars by thermal and x-ray diffraction techniques, Thermochimica Acta. 1995;269/270:779-95.

[20] Moropoulou A, Cakmak A S, Lohvyn N. Earthquake resistant construction techniques and materials on Byzantine monuments in Kiev. Soil Dynamics and Earthquake Engineering. 2000; 19:603-15. 
[21] I Meir A, Freidin C, Gilead I. Analysis of Byzantine mortars from the Negev Desert, Israel, and subsequent environmental and economic implications, Journal of Archaeological Science. 2005;32:767-73.

[22] Freidin C, Meir I A. Byzantine mortars of the Negev Desert, Construction and Building Materials. 2005;19:19-23.

[23] Moropoulou A, Cakmak A S, Biscontin G, Bakolas A, Zendri E. Advanced Byzantine cement based composites resisting earthquake stresses: the crushed brickylime mortars of Justinian's Hagia Sophia, Construction and Building Materials. 2002;16:543-52.

[24] Moropoulou A, Bakolas A, Moundoulas P, Aggelakopoulou E, Anagnostopoulou S. Optimization of compatible restoration mortars for the earthquake protection of Hagia Sophia. Journal of Cultural Heritage. 2013;14S:147-52.

[25] O'Farrell M, Sabir BB, Wild S. Strength and chemical resistance of mortars containing brick manufacturing clays subjected to different treatments. Cement and Concrete Composites. 2006;28:790-9.

[26] Al-Rawas A, Hago A, Corcoran T, Al-Ghafrial K. Properties of Omani artificial pozzolana (sarooj). Applied Clay Science. 1998;13:275-92.

[27] Ventolà L, Vendrell M, Giraldez P, Merino L. Traditional organic additives improve lime mortars: New old materials for restoration and building natural stone fabrics. Construction and Building Materials. 2011;25:3313-8.

[28] Faria P, Henriques F, Rato V. Comparative evaluation of aerial lime mortars for architectural conservation. Journal of Cultural Heritage. 2008;9:338-46.

[29] Faria-Rodrigues P. Resistance to salts of lime and pozzolan mortars. In: C.Groot E., editor. International RILEM Workshop on Repair Mortars for Historic Masonry: RILEM Publications; 2009. p. 99-110.

[30] Moropoulou A, Bakolas A, Bisbikou K. Investigation of the technology of historic mortars. Journal of Cultural Heritage. 2000;1:45-58.

[31] Moropoulou A, Polikreti K, Bakolas A, Michailidis P. Correlation of physicochemical and mechanical properties of historical mortars and classification by multivariate statistics. Cement and Concrete Research. 2003;33:891-8.

[32] Maravelaki-Kalaitzaki P, Bakolas A, Moropoulou A. Physico-chemical study of Cretan ancient mortars. Cement and Concrete Research. 2003;33:651-61.

[33] Budak M, Akkurt S, Böke H. Evaluation of heat treated clay for potential use in intervention mortars. Applied Clay Science. 2010;49:414-9. 
[34] Cardoso I, Macedo MF, Vermeulen F, Corsi C, Santos Silva A, Rosado L, et al. A Multidisciplinary Approach to the Study of Archaeological Mortars from the Town ofAmmaiain the Roman Province of Lusitania (Portugal). Archaeometry. 2014;56:1-24.

[35] Faria-Rodrigues P, Henriques F. Current Mortars in Conservation_An Overview. Restoration of Buildings and Monuments. 2004;10:609-22.

[36] Matias G, Faria-Rodrigues P, Torres I. Lime mortars with brick dust and grounded particles for ancient masonry: development and evaluation. Historic Mortars Conference HMC2008. Lisbon, Portugal2008.

[37] Matias G, Faria P, Torres I. Natural hydraulic lime mortars: influence of the aggregates. Historic Mortars Conference HMC2013. University of West Scotland, Glasgow, Scotland2013.

[38] Moropoulou A, Bakolas A, Aggelakopoulou E. Evaluation of pozzolanic activity of natural and artificial pozzolans by thermal analysis. Thermochimica Acta. 2004;420:135-40.

[39] Naceri A, Hamina MC. Use of waste brick as a partial replacement of cement in mortar. Waste management. 2009;29:2378-84.

[40] Baronio G, Binda L. Study of the pozzolanicity of some bricks and clays. Construction and Building Materials. 1997;11:41-6.

[41] Cardiano P, loppolo S, De Stefano C, Pettignano A, Sergi S, Piraino P. Study and characterization of the ancient bricks of monastery of "San Filippo di Fragalà" in Frazzanò (Sicily). Analytica Chimica Acta. 2004;519:103-11.

[42] Chen J, Thomas J, Taylor H F W, Jennings H M. Solubility and structure of calcium silicate hydrate. Cement and Concrete Research. 2004;34:1499-519.

[43] Velosa A. Lime mortars with pozzolans for old masonry coating (in Portuguese) [PhD]. Aveiro, Portugal: Aveiro University; 2006.

[44] Taylor H F W. The chemistry of cements.1972. Academic Press.

[45] Marques SF, Ribeiro RA, Silva LM, Ferreira VM, Labrincha JA. Study of rehabilitation mortars: Construction of a knowledge correlation matrix. Cement and Concrete Research. 2006;36:1894-902.

[46] Stefanidou M, Pachta V, Konopissi S, Karkadelidou F, Papayianni I. Analysis and characterization of hydraulic mortars. Materials and Structures. 2014;47-4:571-580.

[47] Faria-Rodrigues P. Mortars for old masonry renders - the influence of binders (in Portuguese) [PhD]. Lisbon: NOVA University of Lisbon; 2004. 
[48] CEN. EN 196-5 - Methods of testing cement. Part 5: Pozzolanicity test for pozzolanic cement. Brussels, Belgium: CEN; 2011.

[49] Chakchouk A, Samet B, Mnif T. Study on the potential use of Tunisian clays as pozzolanic material. Applied Clay Science. 2006;33:79-88.

[50] Miriello D, Bloise A, Crisci GM, Barrese E, Apollaro C. Effects of Milling: A Possible Factor Influencing the Durability of Historical Mortars. Archaeometry. 2009.

[51] He C, Osbaeck B, Makovicky E. Pozzolanic reactions of six principal clay minerals - Activation reactivity assessments and thecnological effects. Cement and Concrete Research. 1995;25:1691-702.

[52] O'Farrell M, Wild S, Sabir BB. Pore size distribution and compressive strength of waste clay brick mortar. Cement \& Concrete Composites. 2003;21:81-91.

[53] Toledo Filho RD, Gonçalves JP, Americano BB, Fairbairn EMR. Potential for use of crushed waste calcined-clay brick as a supplementary cementitious material in Brazil. Cement and Concrete Research. 2007;37:1357-65.

[54] Silva J, Brito Jd, Veiga R. Incorporation of fine ceramics in mortars. Construction and Building Materials. 2009;23:556-64.

[55] Lavat AE, Trezza MA, Poggi M. Characterization of ceramic roof tile wastes as pozzolanic admixture. Waste management. 2009;29:1666-74.

[56] Pereira-de-Oliveira LA, Castro-Gomes JP, Santos PMS. The potential pozzolanic activity of glass and red-clay ceramic waste as cement mortars components. Construction and Building Materials. 2012;31:197203.

[57] Teutonico JM, McCaig I, Burns C, Ashurst J. The Smeaton Project - Factors affecting the properties of lime based mortars. Bull Assoc Preservat Technol 1994;25:32-49.

[58] Cortina MG, Dominguez LD. Aired-Lime and chamotte hydraulic mortars. Materials and Construction. 2002;52:65-76.

[59] Charola E, Faria-Rodrigues P, McGhie A, Henriques F. Pozzolanic components in Lime Mortars: Correlating Behaviour Composition and Microstructure. Restoration of Buildings and Monuments. 2005;11:111-8.

[60] Moropoulou A, Bakolas A, Moundoulas P, Aggelakopoulou E, Anagnostopoulou S. Strength development and lime reaction in mortars for repairing historic masonries. Cement and Concrete Composites. 2005;27:289-94. 
[61] Veiga MR, Fragata A, Velosa A, Magalhães AC, Margalha, G. Lime-Based Mortars: Viability for Use as Substitution Renders in Historical Buildings. International Journal of Architectural Heritage. 2010;4:177-95.

[62] Vejmelková E, Keppert M, Rovnaníková P, Keršner Z, Černý R. Application of burnt clay shale as pozzolan addition to lime mortar. Cement and Concrete Composites. 2012;34:486-92.

[63] E-PRTR. The European Pollutant Release and Transfer Register:. Copenhagen, Denmark: European Environment Agency (EEA); 2013.

[64] Andrade I. Relatório de Desperdícios da Indústria Cerâmica - Região Centro 2003. In: CCDRC, editor. Região Centro: CCDRC; 2004.

[65] de Brito J, Pereira AS, Correia JR. Mechanical behaviour of non-structural concrete made with recycled ceramic aggregates. Cement and Concrete Composites. 2005;27:429-33.

[66] Corinaldesi V, Moriconi G. Behaviour of cementitious mortars containing different kinds of recycled aggregate. Construction and Building Materials. 2009;23:289-94.

[67] Correia JR, Brito J, Pereira AS. Effects on concrete durability of using recycled ceramic aggregates. Materials and Structures. 2006;39:169-77.

[68] Debieb F, Kenai S. The use of coarse and fine crushed bricks as aggregate in concrete. Construction and Building Materials. 2008;22:886-93.

[69] Gomes M, Brito J. Structural concrete with incorporation of coarse recycled concrete and ceramic aggregates: durability performance. Materials and Structures. 2008;42:663-75.

[70] Miranda LFR, Selmo SMS. CDW recycled aggregate renderings: Part I - Analysis of the effect of materials finer than $75 \mu \mathrm{m}$ on mortar properties. Construction and Building Materials. 2006;20:615-24.

[71] Corinaldesi V. Environmentally-friendly bedding mortars for repair of historical buildings. Construction and Building Materials. 2012;35:778-84.

[72] Jiménez JR, Ayuso J, López M, Fernández JM, de Brito J. Use of fine recycled aggregates from ceramic waste in masonry mortar manufacturing. Construction and Building Materials. 2013;40:679-90.

[73] IPCC FAR. Climate Change 2007 - The Physical Science Basis - Contribution of Working Group I. UK: Cambridge University Press; 2007.

[74] Faria-Rodrigues P. Resistance to chlorides and sulfates of air lime mortars with different pozzolans (in Portuguese). COMPASS Seminar - Soluble Salts in Mortars for Old Buildings - Damage, Processes and Solutions. LNEC, Lisbon: LNEC; 2005. 